\title{
Upaya Meningkatkan Hasil Belajar Siswa Kelas VIII A SMP Negeri 1 Buntulia Pada Mata Pelajaran Pendidikan Agama Islam Melalui Penerapan Model Pembelajaran Kooperatif tipe Think Talk Write
}

\author{
Warni Diange \\ Guru PAI SMP Negeri 1 Buntulia Gorontalo \\ warnidiange@gmail.com
}

Received: 12 Januari 2021; Revised: 26 Februari 2021; Accepted: 28 April 2021

DOI: http://dx.doi.org/10.37905/aksara.7.2.201-214.2021

\begin{abstract}
Abstrak
Penelitian ini merupakan Penelitian Tindakan Kelas (PTK) dengan mencoba menerapan salah satu model pembelajaran untuk mengaktifkansiswa dan mengefektifkan proses pembelajaran yaitu pembelajaran kooperatif tipe Think Talk Write. Rumusan masalah dalam penelitian ini apakah model pembelajaran kooperatif tipe Think Talk Write dapat meningkatkan hasil belajar siswa pada mata pelajaran Pendidikan Agama Islam di kelas VIII A SMP Negeri 1 Buntulia. Sedangkan yang menjadi tujuan penelitian ini adalahuntuk memperoleh gambaran model pembelajaran kooperatif tipe Think Talk Write dapat meningkatkan hasil belajar siswa pada mata pelajaran Pendidikan Agama Islam di kelas VIII A SMP Negeri 1 Buntulia. Subjek dalam penelitian ini adalah siswa kelas VIII A SMP Negeri 1 Buntulia yang terdiri dari 23 siswa. Instrumen yang digunakan dalam penelitian ini adalah lembar observasi untuk aktivitas guru dan siswa. Soal tes untuk hasil belajar siswa dengan menggunakan rumus persentase.Berdasarkan analisis dari hasil penelitian yang dilakukan di kelas kelas VIII SMP Negeri 1 Buntulia dengan subjek penelitian adalah siswa kelas VIII A sebanyak 23 siswa, dapat di simpulkan bahwa model pembelajaran kooperatif tipe Think Talk Write dapat meningkatkan hasil belajar siswa kelas VIII A SMP Negeri 1 Buntulia yakni dari yang tuntas berjumlah 8 siswa $(34,78 \%)$ menjadi 20 siswa yang tuntas $(86,96 \%)$. Hal ini berarti ada peningkatan yang signifikan sebesar 52,18\%. Kata Kunci: Pembelajaran Kooperatif, Think Talk Write, Hasil Belajar
\end{abstract}

\begin{abstract}
This research is a Classroom Action Research by trying to apply one of the learning models to activate students and make the learning process effective, namely cooperative learning type Think Talk Write. The formulation of the problem in this study is whether the Think Talk Write type of cooperative learning model can improve student learning outcomes in the subject of Islamic Religious Education in class VIII A SMP Negeri 1 Buntulia. Meanwhile, the purpose of this study is to obtain an overview of the Think Talk Write type of cooperative learning model which can improve student learning outcomes in the subject of Islamic Religious Education in class VIII A of SMP Negeri 1 Buntulia. The subjects in this study were students of class VIII A SMP Negeri 1 Buntulia which consisted of 23 students. The instrument used in this study was an observation sheet for teacher and student activities. The test questions for student learning outcomes using the percentage formula. Based on the analysis of the results of research conducted in class VIII SMP Negeri 1 Buntulia with 23 students of class VIII A, it can be concluded that the cooperative learning model Think Talk Write can improve student learning outcomes of class VIII A SMP Negeri 1 Buntulia from 8 students (34.78\%) to 20 students who complete (86.96\%). This means that there is a significant increase of $52.18 \%$.
\end{abstract}

Keywords: Cooperative Learning, Think Talk Write, Learning Outcomes 


\section{PENDAHULUAN}

Belajar mengajar merupakan suatu kegiatan yang bernilai edukatif, dimana nilai edukatif tersebut telah mewarnai interaksi yang terjadi antara guru dengan peserta didik. Interaksi yang bernilai edukatif dikarenakan kegiatan belajar mengajar yang dilakukan, diarahkan untuk mencapai tujuan tertentu yang telah dirumuskan sebelum pengajaran dilakukan. Dapat di katakan telah berhasil dalam belajar jika seseorang mampu menunjukkan adanya perubahan dalam dirinya. Perubahan-perubahan tersebut meliputi perubahan dari kemampuan berpikir (kognitif), sikap (afektif), dan keterampilannya (psikomotor). Unsur penting yang ada dalam kegiatan pembelajaran adalah guru. Guru sebagai pengajar yang memberikan ilmu pengetahuan sekaligus pendidik yang mengajarkan nilai-nilai, akhlak, moral maupun sosial dan untuk menjalankan peran tersebut seorang guru dituntut untuk memiliki pengetahuan dan wawasan yang luas yang nantinya akan diajarkan kepada siswa. Seorang guru dalam menyampaikan materi perlu memilih metode mana yang sesuai dengan keadaan kelas atau siswa sehingga siswa merasa tertarik untuk mengikuti pelajaran yang diajarkan. Dengan variasi metode dapat meningkatkan kegiatan belajar siswa. Menyampaikan pelajaran Pendidikan Agama Islam kepada siswa bukanlah hal yang mudah sebab pelajaran Pendidikan Agama Islam bukan hanya untuk diketahui saja ataupun untuk di hafal, melainkan dapat diterapkan dalam kehidupan nyata. Pendidikan Agama Islam (PAI) merupakan salah satu mata pelajaran yang diberikan kepada siswa mulai dari tingkat dasar sampai perguruan tinggi yang syarat dengan muatan nilai. Mata pelajaran PAI juga sebaiknya mendapat waktu yang proporsional, bukan hanya di madrasah atau sekolah-sekolah yang bernuansa Islam, tetapi di sekolah umum. Demikian pula halnya dalam peningkatan mutu pendidikan, PAI harus dijadikan tolak ukur dalam membentuk watak dan kepribadian peserta didik serta membangun moral bangsa

Pendidikan Agama Islam adalah suatu usaha untuk membina dan mengasuh peserta didik agar senantiasa dapat memahami kandungan ajaran Islam secara menyeluruh, menghayati makna tujuan, yang pada akhirnya dapat mengamalkan serta menjadikan Islam sebagai pandangan hidup. (Majid, 2012: 12). Dimyati dan Mudjiono (2009 : 250), mereka menyatakan dalam bukunya bahwa: Hasil belajar merupakan hal yang dapat dipandang dari dua sisi yaitu sisi peserta didik dan dari sisi pendidik. Dari sisi peserta didik, hasil belajar merupakan tingkat perkembangan mental yang lebih baik bila dibandingkan pada saat sebelum belajar. Tingkat perkembangan mental tersebut terwujud pada jenis-jenis ranah kognitif, afektif, dan psikomotorik. Sedangkan dari sisi pendidik, hasil belajar merupakan saat terselesaikannya bahan pelajaran. Menurut teori Wasliman (dalam Susanto, 2013 :12), hasil belajar yang dicapai oleh peserta didik merupakan hasil interaksi antara berbagai faktor yang memengaruhi, baik faktor internal maupun eksternal. Faktor internal merupakan faktor yang bersumber dari dalam diri peserta didik, yang memengaruhi kemampuan belajarnya. Faktor internal ini meliputi: kecerdasan, minat dan perhatian, motivasi belajar, ketekunan, sikap, kebiasaan belajar, serta kondisi fisik dan kesehatan. Faktor eksternal merupakan Faktor yang berasal dari luar diri peserta didik yang memengaruhi hasil belajar yaitu keluarga, sekolah, dan masyarakat 
Rendahnya hasil belajar tampak pada hasil ujian pra siklus kelas VIII A SMP Negeri 1 Buntulia tahun pelajaran 2018/2019. Nilai rata-rata kelas yang diperoleh dari hasil ujian tengah semester yaitu 58,70. Ada beberapa siswa yang belum mencapai Kriteria Ketuntasan Minimal (KKM) yang telah ditentukan yaitu 70, dari seluruh siswa kelas VIII A SMP Negeri 1 Buntulia yang berjumlah 23 orang, hanya ada 8 siswa atau sekitar 34,78\% yang telah mencapai KKM dan 15 siswa atau 65,22\% yang belum mencapai KKM. Angka tersebut didapatkan dari dokumentasi hasil belajar. Melihat fakta-fakta yang dipaparkan tersebut, perlu adanya perbaikan pembelajaran dalam kelas.

Rendahnya aktivitas dan hasil belajar serta berbagai masalah di atas dipengaruhi oleh banyak faktor. Pemilihan model pembelajaran yang tepat dapat membantu guru mengatasi masalah-masalah tersebut, sehingga tujuan dalam pelaksanaan pembelajaran dapat tercapai. Salah satu model pembelajaran yang dapat dijadikan alternatif bagi guru untuk menjadikan kegiatan pembelajaran PAI berlangsung efektif dan optimal yaitu dengan menggunakan model pembelajaran kooperatif tipe Think Talk Write (TTW) untuk membuat siswa lebih aktif, kreatif dan kondusif dalam pembelajaran. Model pembelajaran kooperatif tipe Think Talk Write (TTW) diperkenalkan oleh Huinker \& Laughlin. Pada dasarnya pembelajaran ini dibangun melalui proses berpikir, berbicara dan menulis. Strategi pembelajaran Think Talk Write (TTW) dapat menumbuh kembangkan kemampuan pemecahan masalah (Yamin dan Ansari, 2012: 84). Alur kemajuan pembelajaran TTW dimulai dari keterlibatan siswa dalam berpikir atau berdialog dengan dirinya sendiri setelah proses membaca, selanjutnya berbicara dan membagi ide dengan temannya sebelum menulis.

Model Pembelajaran Kooperatif tipe Think Talk Write (TTW) adalah model pembelajaran yang dibangun melalui berpikir, berbicara, dan menulis. Dalam penerapannya siswa diberikan materi atau soal untuk dikerjakan dan dipahami sesuai bahasa sendiri (berpikir). Setelah bertukar pendapat siswa bertugas untuk membuat rangkuman atau jawaban dari materi ataupun soal yang telah didiskusikan (menulis).



Gambar 1

Ilustrasi Think Talk Write

Berdasarkan tinjauan pustaka di atas, dapat dirumuskan hipotesis tindakannya yaitu "penerapan model pembelajaran kooperatif tipe Think Talk Write (TTW) pada 
mata pelajaran Pendidikan Agama Islam dapat meningkatkan hasil belajar siswa kelas VIII A SMP Negeri 1 Buntulia"

\section{METODE PENELITIAN}

Jenis penelitian ini adalah kualitatif dengan menggunakan metode penelitian tindakan kelas (PTK). Secara sederhana, PTK dilaksanakan berupa proses pengkajian berdaur (circle), seperti yang digunakan oleh Kutr Lewin dalam penelitiannya. Konsep dan skema penelitian tindakan kelas pada model pembelajaran kooperatif tipe TTW terdiri dari empat komponen. Siklus tersebut sebagaimana digambarkan pada skema gambar dibawah ini.

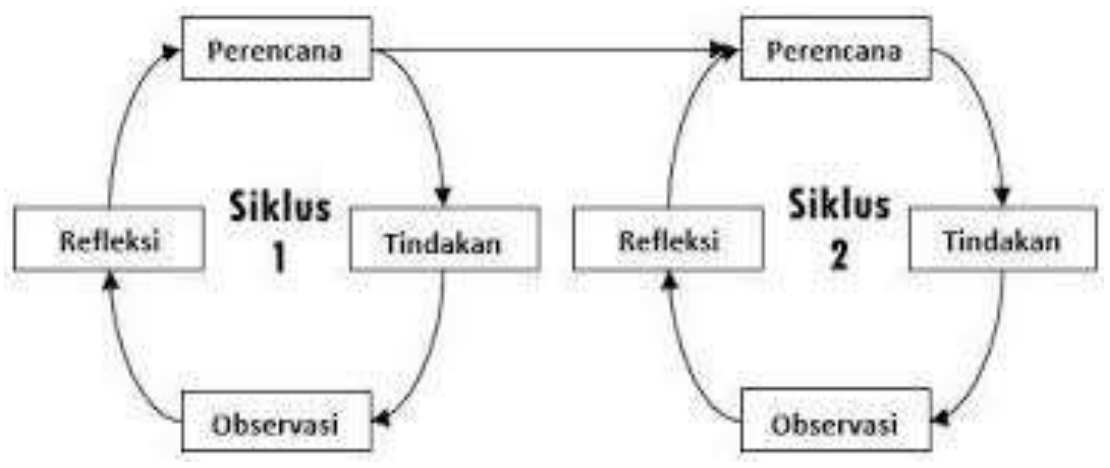

Gambar 2

Siklus PTK

Objek dalam penelitian ini adalah penerapan model pembelajaran Think, Talk, Write (TTW) untuk meningkatkan hasil belajar siswa pada matapelajaran Pendidikan Agama Islam di SMP Negeri 1 BuntuliaSedangkan subjek dalam penelitian ini adalah :

a. Guru mata pelajaran Pendidikan Agama Islam di SMP Negeri 1 Buntulia

b. Siswa kelas VIII A di SMP Negeri 1 Buntulia

Adapun teknik analisis data untuk masing-masing data dalam penelitian ini adalah sebagai berikut:

1. Analisis Aktivitas Guru Dan Siswa

Data aktivitas guru dan siswa diperoleh dari lembar pengamatan yang diisi oleh pengamat selama pembelajaran berlangsung. Rumus persentase untuk melihat kecenderungan yang terjadi dalam proses pembelajaran adalah sebagai berikut :

$$
P=\frac{F}{N} \times 100 \%
$$

Keterangan:

$\mathrm{P}=$ Angka Presentase

$\mathrm{F}=$ Frekuensi

$\mathrm{N}=$ Jumlah Siswa Seluruhnya 
Tabel 1

Kategori Kriteria Penilaian Hasil Pengamatan Guru Dan Siswa

\begin{tabular}{|c|c|c|}
\hline No & Nilai $(\%)$ & Kategori \\
\hline 1 & $80-100$ & Baik Sekali \\
\hline 2 & $66-79$ & Baik \\
\hline 3 & $56-65$ & Cukup \\
\hline 4 & $40-55$ & Kurang \\
\hline 5 & $30-39$ & Gagal \\
\hline
\end{tabular}

2. Analisis Hasil Belajar

Untuk mengetahui apakah terjadi peningkatan hasil belajar siswa kelas VIII A SMP Negeri 1 Buntulia melalui penerapan model pembelajaran kooperatif tipe Think Talk Write, dianalisis dengan statistik deskriptif yaitu dengan menggunakan rumus:

Keterangan:

$$
P=\frac{F}{N} \times 100 \%
$$

$\mathrm{P}=$ Angka Presentase

$\mathrm{F}=$ Frekuensi

$\mathrm{N}=$ Jumlah Siswa Seluruhnya

Tabel 2

Kategori Kriteria Penilaian Hasil Belajar Siswa

\begin{tabular}{|c|c|c|}
\hline No & Nilai (\%) & Kategori \\
\hline 1 & $80-100$ & Baik Sekali \\
\hline 2 & $66-79$ & Baik \\
\hline 3 & $56-65$ & Cukup \\
\hline 4 & $40-55$ & Kurang \\
\hline 5 & $30-39$ & Gagal \\
\hline
\end{tabular}

Penelitian ini dapat dikatakan berhasil apabila hasil belajar siswa yang mendapat nilai sesuai KKM mata pelajaran Pendidikan Agama Islam yaitu 70 mencapai $\geq 75 \%$ dari jumlah siswa.

\section{PEMBAHASAN}

Siklus I

1) Aktivitas Guru

Pada tahap ini, instrumen yang digunakan berupa lembar observasiaktivitas guru. Aktivitas guru diamati oleh teman sejawat yang juga mengajar Pendidikan Agama Islam. Data hasil aktivitas guru pada siklus I pada tabel berikut: 
Tabel 4

Hasil Pengamatan Aktivitas Guru Siklus I

\begin{tabular}{|c|c|c|c|c|c|c|}
\hline No & Indikator & 1 & 2 & 3 & 4 & 5 \\
\hline 1 & $\begin{array}{l}\text { Kemampuan melakukan apersepsi, tanya jawab tentang } \\
\text { materi sebelumnya dengan materi yang akan dipelajari }\end{array}$ & & & & $\sqrt{ }$ & \\
\hline 2 & Kemampuan guru dalam membagi kelompok & & & & $\sqrt{ }$ & \\
\hline 3 & $\begin{array}{l}\text { Kemampuan guru dalam menyampaikan tujuan } \\
\text { pembelajaran }\end{array}$ & & & & $\sqrt{ }$ & \\
\hline 4 & Kemampuan guru dalam penguasaan materi & & & & $\sqrt{ }$ & \\
\hline 5 & $\begin{array}{l}\text { Kemampuan guru membimbing siswa membuat catatan } \\
\text { kecil setelah membaca dan mengamati }\end{array}$ & & & $\sqrt{ }$ & & \\
\hline 6 & $\begin{array}{l}\text { Kemampuan guru membimbing siswa menyelesaikan } \\
\text { permasalahan dalam diskusi }\end{array}$ & & & $\sqrt{ }$ & & \\
\hline 7 & $\begin{array}{l}\text { Kemampuan guru membimbing siswa menuliskan hasil } \\
\text { diskusi }\end{array}$ & & & & $\sqrt{ }$ & \\
\hline 8 & $\begin{array}{l}\text { Kemampuan guru meminta siswa mempresentasikan } \\
\text { hasil yang telah didiskusikan dalam kelompoknya }\end{array}$ & & & & $\sqrt{ }$ & \\
\hline 9 & $\begin{array}{l}\text { Kemampuan mendorong siswa untuk bertanya dan } \\
\text { menjawab pertanyaan }\end{array}$ & & & $\sqrt{ }$ & & \\
\hline 10 & $\begin{array}{l}\text { Kemampuan guru mengarahkan siswa untuk menarik } \\
\text { kesimpulan tentang materi yang dipelajari }\end{array}$ & & & $\sqrt{ }$ & & \\
\hline & Jumlah & \multicolumn{5}{|c|}{36} \\
\hline & Presentae & \multicolumn{5}{|c|}{72} \\
\hline & Kategori & \multicolumn{5}{|c|}{ Baik } \\
\hline
\end{tabular}

Keterangan skor penilaian :

5 = baik sekali

4 = baik

$3=$ cukup

$2=$ kurang

$1=$ sangat kurang

Hasil observasi pada tabel 4 diatas menunjukkan bahwa kegiatan pembelajaran melalui model pembelajaran kooperatif Think Talk Write (TTW) pada siklus I mendapatkan skor persentase $72 \%$. Berdasarkan kategori penilaian persentase $72 \%$ berada pada kategori baik dan masih ada beberapa kemampuan yang perlu ditingkatkan yaitu: pertama, Kemampuan guru memotivasi siswa dalam mengaitkan pengalaman pribadi siswa dalam kehidupan sehari-hari dengan materi yang akan dipelajari. Kedua Kemampuan guru membimbing siswa membu at catatan kecil setelah membaca dan mengamati. Ketiga, Mengembangkan kegiatan Tanya jawab. Keempat, Kemampuan guru mengarahkan siswa untuk menarik kesimpulan tentang materi yang dipelajari. Selain dari itu, perlu juga adanya peningkatan kualitas pada aspek aspek yang sudah baik agar hasil pembelajaran tercapai dengan maksimal 


\section{2) Aktivitas Siswa}

Pada tahap ini adalah kegiatan mengamati aktivitas siswa pada saat pembelajaran berlangsung, dari awal sampai akhir untuk setiap pertemuan. Hasil pengamatan aktivitas siswa pada siklus I dapat dilihat pada tabel 5 berikut

Tabel 5

Hasil Pengamatan Aktivitas Siswa Pada Siklus I

\begin{tabular}{|c|c|c|c|c|c|c|c|}
\hline $\mathrm{No}$ & Indikator & Aspek Pengamatan & 1 & 2 & 3 & 4 & 5 \\
\hline \multirow{4}{*}{1} & \multirow{4}{*}{$\begin{array}{lr}\text { Keteriban peserta } \\
\text { didik } & \text { dalam } \\
\text { pembelajaran } & \end{array}$} & $\begin{array}{l}\text { Suasana kelas tenang dan peserta } \\
\text { didik mengkondisikan diri dalam } \\
\text { pembelajaran }\end{array}$ & & & $\sqrt{ }$ & & \\
\hline & & $\begin{array}{l}\text { Keseriusan peserta didik dalam } \\
\text { mengikuti pelajaran }\end{array}$ & & & & $\sqrt{ }$ & \\
\hline & & $\begin{array}{l}\text { Peserta didik memperhatikan } \\
\text { penjelasan guru tentang materi } \\
\text { yang di ajarkan dengan seksama }\end{array}$ & & & & $\sqrt{ }$ & \\
\hline & & $\begin{array}{l}\text { Peserta didik melaksanakan } \\
\text { tugas sesuai dengan petunjuk } \\
\text { guru dengan baik dan teratur }\end{array}$ & & & & $\sqrt{ }$ & \\
\hline \multirow{4}{*}{2} & \multirow{4}{*}{$\begin{array}{l}\text { Keaktifan } \\
\text { Dalam pembelajaran }\end{array}$} & $\begin{array}{l}\text { Keberanian peserta didik dalam } \\
\text { menjawab pertanyaan }\end{array}$ & & & & $\sqrt{ }$ & \\
\hline & & $\begin{array}{l}\text { Keberanian peserta didik dalam } \\
\text { mengajukan pertanyaan }\end{array}$ & & & & $\sqrt{ }$ & \\
\hline & & $\begin{array}{l}\text { Keberaniaan peserta didik dalam } \\
\text { mempresentasikan } \\
\text { diskusinya }\end{array}$ & & & $\sqrt{ }$ & & \\
\hline & & $\begin{array}{l}\text { Keberanian peserta didik dalam } \\
\text { memberikan tanggapan }\end{array}$ & & & $\sqrt{ }$ & & \\
\hline \multicolumn{3}{|c|}{ Jumlah } & \multicolumn{5}{|c|}{29} \\
\hline \multicolumn{3}{|c|}{ Presentase } & \multicolumn{5}{|c|}{72,5} \\
\hline \multicolumn{3}{|c|}{ Kategori } & \multicolumn{5}{|c|}{ Baik } \\
\hline
\end{tabular}

Berdasarkan data diatas, maka hasil observasi pada tabel 5 diatas menunjukkan bahwa kegiatan pembelajaran melalui model pembelajaran kooperatif tipe Think Talk Write(TTW) pada siklus I mendapatkan skor persentase $72,5 \%$. Berdasarkan kategori penilaian persentase $72,5 \%$ berada pada kategori baik, namun masih ada beberapa aktivitas yang perlu ditingkatkan yaitu: pertama, Siswa di harapkan lebih memperhatikan penjelasan guru tentang proses pembelajaran yang akan di laksanakan. Kedua, lebih aktif dalam mengajukan pertanyaan tentang materi iman kepada kitab kitab Allah SWT.

\section{3) Hasil Belajar Siswa}

Setelah dilakukan kegiatan pembelajaran pada RPP I, guru memberikan soal tes untuk mengetahui kemampuan siswa setelah diterapkan model pembelajaran kooperatif tipe Think Talk Write (TTW) yang diikuti oleh 23 siswa. Skor hasil tes belajar siswa pada RPP I dapat dilihat pada tabel 6 berikut: 
Tabel 6

Nilai Siklus I

\begin{tabular}{|c|c|c|c|}
\hline No & Nama Siswa & Nilai & Keterangan \\
\hline 1 & Abdul Razak Pasiali & 80 & Tuntas \\
\hline 2 & Abdjul Djumaati & 75 & Tuntas \\
\hline 3 & Andriyanto Biko & 50 & Belum Tuntas \\
\hline 4 & Arlan Daud & 60 & Belum Tuntas \\
\hline 5 & Aldi Latif & 75 & Tuntas \\
\hline 6 & Idris Umar & 50 & Belum Tuntas \\
\hline 7 & Nur Lasimpala & 70 & Tuntas \\
\hline 8 & Rezki Djafar & 90 & Tuntas \\
\hline 9 & Rikal Tobamba & 50 & Belum Tuntas \\
\hline 10 & Adelia Ambo & 40 & Belum Tuntas \\
\hline 11 & Anisa Hanga & 85 & Tuntas \\
\hline 12 & Fatmawati Hunowu & 50 & Belum Tuntas \\
\hline 13 & Hapsa Hasan & 90 & Tuntas \\
\hline 14 & Hasrita Kobi & 70 & Tuntas \\
\hline 15 & Irwati Potale & 85 & Tuntas \\
\hline 16 & Kristika Sabuge & 80 & Tuntas \\
\hline 17 & Melisa Daud & 70 & Tuntas \\
\hline 18 & Petriyanti Pambi & 85 & Tuntas \\
\hline 19 & Sri Julianti Kolombengi & 60 & Belum Tuntas \\
\hline 20 & Windi Paue & 55 & Belum Tuntas \\
\hline 21 & Rapika Djou & 85 & Tuntas \\
\hline 22 & Sariyanti Putri Karim & 75 & Tuntas \\
\hline 23 & Danial Kobi & 90 & Tuntas \\
\hline \multicolumn{4}{|c|}{ Skor tertinggi } \\
\hline & Skor terendah & \multicolumn{2}{|c|}{40} \\
\hline & Jumlah Skor & \multicolumn{2}{|c|}{1620} \\
\hline & Rata - rata & \multicolumn{2}{|c|}{70,43} \\
\hline & $\%$ ketuntasan & \multicolumn{2}{|c|}{60,87} \\
\hline & $\%$ Belum tuntas & \multicolumn{2}{|c|}{39,13} \\
\hline
\end{tabular}

Keterangan skor penilaian :

5 = baik sekali

4 = baik

$3=$ cukup

$2=$ kurang

$1=$ sangat kurang

Berdasarkan hasil tes siklus I pada tabel 6 di atas diketahui bahwa sebanyak 14 siswa $(60,87 \%)$ tuntas belajar secara individu pada materi iman kepada kitab kitab Allah swt, sedangkan sebanyak 9 siswa $(39,13 \%)$ belum tuntas belajar. Oleh karena itu dapat disimpulkan bahwa ketuntasan belajar siswa secara klasikal untuk siklus I belum tuntas 
Secara umum, penjelasan tentang hasil permasalahan untuk aspek - aspek yang perlu diperbaiki selama proses pembelajaran pada siklus I dapat dilihat pada tabel 7 berikut:

Tabel 7

Hasil Temuan dan Revisi Selama Proses Pembelajaran Siklus I

\begin{tabular}{|c|c|c|c|}
\hline No & Refleksi & Hasil Temuan & Tindak Lanjut \\
\hline \multirow{3}{*}{1} & \multirow{3}{*}{ Aktivitas Guru } & $\begin{array}{l}\text { Kurang mampu } \\
\text { memotivasi siswa dalam } \\
\text { mengaitkan pengalaman } \\
\text { pribadi siswa dalam } \\
\text { kehidupan sehari-hari } \\
\text { dengan materi yang akan } \\
\text { dipelajari }\end{array}$ & $\begin{array}{l}\text { Pertemuan selanjutnya } \\
\text { agar mampu memotivasi } \\
\text { siswa dalam mengaitkan } \\
\text { pengalaman pribadi siswa } \\
\text { dalam kehidupan sehari } \\
\text { hari dengan materi yang } \\
\text { akan dipelajari }\end{array}$ \\
\hline & & $\begin{array}{l}\text { Kemampuan mendorong } \\
\text { siswa untuk bertanya dan } \\
\text { menjawab pertanyaan }\end{array}$ & $\begin{array}{l}\text { Pertemuan selanjutnya } \\
\text { agar mampu mendorong } \\
\text { siswa untuk bertanya dan } \\
\text { menjawab pertanyaan } \\
\text { dengan memberi reward }\end{array}$ \\
\hline & & $\begin{array}{l}\text { Kemampuan guru } \\
\text { mengarahkan siswa untuk } \\
\text { menarik } \\
\text { kesimpulan tentang } \\
\text { materi yang dipelaja }\end{array}$ & $\begin{array}{l}\text { Pada pertemuan } \\
\text { selanjutnya agar } \\
\text { mengarahkan siswa untuk } \\
\text { menarik kesimpulan } \\
\text { tentang materi }\end{array}$ \\
\hline \multirow[b]{2}{*}{2} & \multirow[b]{2}{*}{ Aktivitas Siswa } & $\begin{array}{l}\text { Kurang mengajukan } \\
\text { pertanyaan tentang } \\
\text { materi yang dipelajari }\end{array}$ & $\begin{array}{l}\text { Pada pertemuan } \\
\text { selanjutnya guru harus } \\
\text { memancing siswa untuk } \\
\text { bertanya tentang materi } \\
\text { yang dipelajari dengan } \\
\text { memberikan reward } \\
\end{array}$ \\
\hline & & $\begin{array}{l}\text { Kurangnya partisipasi } \\
\text { dalam membahas isi } \\
\text { catatan dalam diskusi } \\
\text { kelompok }\end{array}$ & $\begin{array}{l}\text { Pada pertemuan } \\
\text { selanjutnya dalam } \\
\text { membahas isi catatan } \\
\text { dalam diskusi kelompok } \\
\text { guru harus } \\
\text { mengelompokkan siswa } \\
\text { dengan kelompok kecil }\end{array}$ \\
\hline 3 & $\begin{array}{l}\text { Hasil Belajar } \\
\text { Siswa }\end{array}$ & $\begin{array}{l}\text { Masih ada } 9 \text { siswa yang } \\
\text { hasil belajarnya belum } \\
\text { mencapai skor } \\
\text { ketuntasan }\end{array}$ & $\begin{array}{l}\text { Pada tahap selanjutnya } \\
\text { guru akan lebih } \\
\text { menekankan dalam } \\
\text { menjelaskan materi } \\
\text { iman kepada kitab kitab } \\
\text { Allah SWT }\end{array}$ \\
\hline
\end{tabular}

Terlihat dari tabel hasil belajar siswa masih ada 9 siswa yang belumtuntas. Hal ini disebabkan kesulitan-kesulitan yang mereka hadapi yaitu: pertama, Siswa kurang memperhatikan penjelasan guru tentang proses pembelajaran yang akan di 
laksanakan. Kedua, Guru Kurang mampu memotivasi siswa dalam mengaitkan pengalaman pribadi siswa dalam kehidupan sehari-hari dengan materi yang akan dipelajari. Ketiga, siswa kurang aktif dalam mengajukan pertanyaan tentang materi iman kepada kitab - kitab Allah SWT. Keempat, Kurangnya partisipasi Pada pertemuan dalam membahas isi catatan dalam diskusi kelompok. Kelima, belum maksimalnya kemampuan Guru mengarahkan siswa untuk menarik kesimpulan tentang materi yang dipelajari.

\section{Siklus II}

1) Aktivitas Guru

Pada tahap ini, pengamatan terhadap aktivitas guru menggunakan instrumen yang berupa lembar observasi aktivitas guru. Data hasil aktivitas guru pada siklus I dapat dilihat pada tabel berikut:

Tabel 8

Hasil Pengamatan Aktivitas Guru Siklus II

\begin{tabular}{|c|c|c|c|c|c|c|}
\hline No & Indikator & 1 & 2 & 3 & 4 & 5 \\
\hline 1 & $\begin{array}{l}\text { Kemampuan melakukan apersepsi, tanya jawab tentang } \\
\text { materi sebelumnya dengan materi yang akan dipelajari }\end{array}$ & & & & $\sqrt{ }$ & \\
\hline 2 & Kemampuan guru dalam membagi kelompok & & & & & $\sqrt{ }$ \\
\hline 3 & $\begin{array}{l}\text { Kemampuan guru dalam menyampaikan tujuan } \\
\text { pembelajaran }\end{array}$ & & & & & $\sqrt{ }$ \\
\hline 4 & Kemampuan guru dalam penguasaan materi & & & & $\sqrt{ }$ & \\
\hline 5 & $\begin{array}{l}\text { Kemampuan guru membimbing siswa membuat catatan } \\
\text { kecil setelah membaca dan mengamati }\end{array}$ & & & & $\sqrt{ }$ & \\
\hline 6 & $\begin{array}{l}\text { Kemampuan guru membimbing siswa menyelesaikan } \\
\text { permasalahan dalam diskusi }\end{array}$ & & & & $\sqrt{ }$ & \\
\hline 7 & $\begin{array}{l}\text { Kemampuan guru membimbing siswa menuliskan hasil } \\
\text { diskusi }\end{array}$ & & & & & $\sqrt{ }$ \\
\hline 8 & $\begin{array}{l}\text { Kemampuan guru meminta siswa mempresentasikan } \\
\text { hasil yang telah didiskusikan dalam kelompoknya }\end{array}$ & & & & & $\sqrt{ }$ \\
\hline 9 & $\begin{array}{l}\text { Kemampuan mendorong siswa untuk bertanya dan } \\
\text { menjawab pertanyaan }\end{array}$ & & & & $\sqrt{ }$ & \\
\hline 10 & $\begin{array}{l}\text { Kemampuan guru mengarahkan siswa untuk menarik } \\
\text { kesimpulan tentang materi yang dipelajari }\end{array}$ & & & & $\sqrt{ }$ & \\
\hline & Jumlah & \multicolumn{5}{|c|}{44} \\
\hline & Presentae & \multicolumn{5}{|c|}{80} \\
\hline & Kategori & \multicolumn{5}{|c|}{ Baik Sekali } \\
\hline
\end{tabular}

Keterangan skor penilaian :

$5=$ baik sekali

4 = baik

$3=$ cukup

$2=$ kurang

$1=$ sangat kurang

Hasil observasi pada tabel 8 diatas menunjukkan bahwa kegiatan pembelajaran melalui model pembelajaran kooperatif Think Talk Write pada siklus 
II mendapatkan skor persentase $80 \%$. Berdasarkan kategori penilaian persentase $80 \%$ berada pada kategori baik sekali dan namun tentu saja ada beberapa kemampuan yang perlu ditingkatkan lagi agar pembelajaran semakin baik lagi.

\section{2) Aktivitas Siswa}

Pada tahap ini adalah kegiatan mengamati aktivitas siswa pada saat pembelajaran berlangsung, dari awal sampai akhir untuk setiap pertemuan. Hasil pengamatan aktivitas siswa pada siklus II dapat dilihat pada tabel 9 berikut :

Tabel 9

Hasil Pengamatan Aktivitas Siswa Pada Siklus II

\begin{tabular}{|c|c|c|c|c|c|c|c|}
\hline No & Indikator & Aspek Pengamatan & 1 & 2 & 3 & 4 & 5 \\
\hline \multirow{4}{*}{1} & \multirow{4}{*}{$\begin{array}{lr}\text { Keteriban } & \text { peserta } \\
\text { didik } & \text { dalam } \\
\text { pembelajaran } & \end{array}$} & $\begin{array}{l}\text { Suasana kelas tenang dan peserta } \\
\text { didik mengkondisikan diri dalam } \\
\text { pembelajaran }\end{array}$ & & & & $\sqrt{ }$ & \\
\hline & & $\begin{array}{l}\text { Keseriusan peserta didik dalam } \\
\text { mengikuti pelajaran }\end{array}$ & & & & & $\sqrt{ }$ \\
\hline & & $\begin{array}{l}\text { Peserta didik memperhatikan } \\
\text { penjelasan guru tentang materi } \\
\text { yang di ajarkan dengan seksama }\end{array}$ & & & & $\sqrt{ }$ & \\
\hline & & $\begin{array}{l}\text { Peserta didik melaksanakan } \\
\text { tugas sesuai dengan petunjuk } \\
\text { guru dengan baik dan teratur }\end{array}$ & & & & & $\sqrt{ }$ \\
\hline \multirow{4}{*}{2} & \multirow{4}{*}{$\begin{array}{l}\text { Keaktifan } \\
\text { Dalam pembelajaran }\end{array}$} & $\begin{array}{l}\text { Keberanian peserta didik dalam } \\
\text { menjawab pertanyaan }\end{array}$ & & & & & $\sqrt{ }$ \\
\hline & & $\begin{array}{l}\text { Keberanian peserta didik dalam } \\
\text { mengajukan pertanyaan }\end{array}$ & & & & $\sqrt{ }$ & \\
\hline & & $\begin{array}{l}\text { Keberaniaan peserta didik dalam } \\
\text { mempresentasikan } \\
\text { diskusinya }\end{array}$ & & & & & $\sqrt{ }$ \\
\hline & & $\begin{array}{l}\text { Keberanian peserta didik dalam } \\
\text { memberikan tanggapan }\end{array}$ & & & & $\sqrt{ }$ & \\
\hline \multicolumn{3}{|c|}{ Jumlah } & \multicolumn{5}{|c|}{36} \\
\hline \multirow{2}{*}{\multicolumn{3}{|c|}{$\frac{\text { Presentase }}{\text { Kategori }}$}} & \multicolumn{4}{|c|}{90} & \\
\hline & & & \multicolumn{5}{|c|}{ Baik Sekali } \\
\hline
\end{tabular}

Keterangan skor penilaian :

$5=$ baik sekali

$4=$ baik

$3=$ cukup

$2=$ kurang

$1=$ sangat kurang

Hasil observasi pada tabel 9 diatas menunjukkan bahwa kegiatan pembelajaran melalui model pembelajaran kooperatif tipe Think TalkWrite(TTW) terhadap aktivitas belajar siswa pada siklus II mendapatkan skor persentase $90 \%$. Berdasarkan kategori penilaian persentase $90 \%$ berada pada kategori baik sekali, namun masih ada beberapa aktivitas yang perlu ditingkatkan agar hasil belajar siswa tercapai dengan maksimal dan lebih baik lagi 


\section{3) Hasil Belajar Siswa}

Setelah dilakukan kegiatan pembelajaran pada RPP II, guru memberikan soal tes untuk mengetahui kemampuan siswa setelah diterapkan model pembelajaran kooperatif tipe Think Talk Write yang diikuti oleh 23 siswa. Skor hasil tes belajar siswa dapat dilihat pada tabel 10 berikut:

Tabel 10

Nilai Siklus II

\begin{tabular}{|c|c|c|c|}
\hline No & Nama Siswa & Nilai & Keterangan \\
\hline 1 & Abdul Razak Pasiali & 90 & Tuntas \\
\hline 2 & Abdjul Djumaati & 80 & Tuntas \\
\hline 3 & Andriyanto Biko & 70 & Tuntas \\
\hline 4 & Arlan Daud & 75 & Tuntas \\
\hline 5 & Aldi Latif & 75 & Tuntas \\
\hline 6 & Idris Umar & 60 & Belum Tuntas \\
\hline 7 & Nur Lasimpala & 95 & Tuntas \\
\hline 8 & Rezki Djafar & 100 & Tuntas \\
\hline 9 & Rikal Tobamba & 75 & Tuntas \\
\hline 10 & Adelia Ambo & 60 & Belum Tuntas \\
\hline 11 & Anisa Hanga & 95 & Tuntas \\
\hline 12 & Fatmawati Hunowu & 75 & Tuntas \\
\hline 13 & Hapsa Hasan & 100 & Tuntas \\
\hline 14 & Hasrita Kobi & 85 & Tuntas \\
\hline 15 & Irwati Potale & 90 & Tuntas \\
\hline 16 & Kristika Sabuge & 100 & Tuntas \\
\hline 17 & Melisa Daud & 95 & Tuntas \\
\hline 18 & Petriyanti Pambi & 85 & Tuntas \\
\hline 19 & Sri Julianti Kolombengi & 75 & Tuntas \\
\hline 20 & Windi Paue & 60 & Belum Tuntas \\
\hline 21 & Rapika Djou & 85 & Tuntas \\
\hline 22 & Sariyanti Putri Karim & 80 & Tuntas \\
\hline 23 & Danial Kobi & 100 & Tuntas \\
\hline & Skor tertinggi & \multicolumn{2}{|c|}{100} \\
\hline & Skor terendah & \multicolumn{2}{|c|}{60} \\
\hline & Jumlah Skor & \multicolumn{2}{|c|}{1905} \\
\hline & Rata - rata & \multicolumn{2}{|c|}{82,83} \\
\hline & $\%$ ketuntasan & \multicolumn{2}{|c|}{86,96} \\
\hline & $\%$ Belum tuntas & \multicolumn{2}{|c|}{13.04} \\
\hline
\end{tabular}

Berdasarkan hasil tes siklus II pada Tabel 10 di atas diketahui bahwa sebanyak 20 siswa $(86,96 \%)$ tuntas belajar secara individu pada materi iman kepada kitab kitab Allah swt, sedangkan sebanyak 3 siswa $(13,04 \%)$ belum tuntas belajar. Oleh karena itu dapat disimpulkan bahwa ketuntasan belajar siswa secara klasikal $75 \%$ untuk siklus II sudah tercapai

Secara umum, penjelasan tentang hasil permasalahan untuk aspek - aspek yang perlu diperbaiki selama proses pembelajaran pada siklus II dapat 
dilihat pada Tabel 11 berikut :

Tabel 11

Hasil Temuan dan Revisi Selama Proses Pembelajaran Siklus II

\begin{tabular}{|l|l|l|l|}
\hline No & \multicolumn{1}{|c|}{ Refleksi } & \multicolumn{1}{|c|}{ Hasil Temuan } & \multicolumn{1}{c|}{ Tindak Lanjut } \\
\hline 1 & Aktivitas Guru & $\begin{array}{l}\text { Kemampuan guru } \\
\text { mengarahkan siswa untuk } \\
\text { menarik kesimpulan } \\
\text { tentang materi yang } \\
\text { dipelajari }\end{array}$ & $\begin{array}{l}\text { Pada pertemuan } \\
\text { selanjutnya agar dapat } \\
\text { mengarahkan siswa untuk } \\
\text { menarik kesimpulan } \\
\text { tentang materi yang } \\
\text { dipelajari }\end{array}$ \\
\hline 2 & Aktivitas Siswa & $\begin{array}{l}\text { Membuat kesimpulan } \\
\text { tentang materi yang } \\
\text { dipelajari }\end{array}$ & $\begin{array}{l}\text { Mengarahkan kepada } \\
\text { siswa untuk membuat } \\
\text { kesimpulan tentang materi } \\
\text { yang dipelajari }\end{array}$ \\
\hline 3 & $\begin{array}{l}\text { Hasil Belajar } \\
\text { Siswa }\end{array}$ & $\begin{array}{l}\text { Masih ada 3 siswa yang } \\
\text { hasil belajarnya belum } \\
\text { mencapai skor } \\
\text { ketuntasan.Bagaimanapun } \\
\text { pada siklus II siswa sudah } \\
\text { mencapai ketuntasan } \\
\text { secara klasikal (86,96\%) }\end{array}$ & $\begin{array}{l}\text { Guru bisa menyediakan } \\
\text { waktu khusus untuk } \\
\text { memberikan bimbingan } \\
\text { kepada siswa yang } \\
\text { belum tuntas }\end{array}$ \\
& \multicolumn{2}{|l|}{} \\
\hline
\end{tabular}

Terlihat dari tabel hasil belajar siswa belum tuntas. Masih ada 4 siswa yang belum tuntas dalam pembelajaran, untuk itu perlu waktu, perhatian,sertabimbingan khusus agar siswa tersebut dapat tuntas dalam pembelajaran.

Adapun data perbandingan hasil belajar siswa pada pra siklus, siklus I, dan II sebagai berikut:

Tabel 12

Data Perbandingan Hasil Belajar Siswa Padapra Siklus, Siklus I, Dan II

\begin{tabular}{|c|c|c|c|c|c|c|}
\hline \multirow{2}{*}{ No } & \multirow{2}{*}{ Pelaksanaan } & \multicolumn{2}{|c|}{ Jumlah Peserta Didik } & \multicolumn{2}{|c|}{ Presentase } & \multirow{2}{*}{$\begin{array}{c}\text { Ketuntasan } \\
\text { Klasikal }\end{array}$} \\
\hline & & Tuntas & B.Tuntas & Tuntas & B.Tuntas & \\
\hline 1 & Pra Siklus & 8 & 15 & 34,78 & 65,22 & 34,78 \\
\hline 2 & Siklus I & 14 & 9 & 60.87 & 39,13 & 60.87 \\
\hline
\end{tabular}

Berdasarkan grafik di atas terbukti adanya peningkatan hasil belajar siswa kelas VIII A SMP Negeri 1 Buntulia tahun 2018/2019, sebelum di terapkan model pembelajaran kooperatif tipe Think Talk Write $(T T W)$ masih rendah. Dengan jumlah 23 siswa, yang pada pembelajaran sebanyak 8siswa dengan presentase 34,78\% sedangkan 15 lainnya dengan presentase $65,22 \%$ tidak tuntas

Setelah di terapkan model pembelajaran kooperatif tipe Think TalkWrite (TTW) pada siklus I mengalami peningkatan dengan jumlah siswa 23 ada 14 siswa yang tuntas dengan presentase $60,87 \%$ dan 9 siswa yang tidak tuntas dengan presentase $39,13 \%$. Pada siklus II dari 23 siswa sebanyak 20 siswa dengan presentase $86,96 \%$ tuntas dan 3 siswa dengan presentase 13,04 tidak tuntas. 


\section{PENUTUP}

Melalui hasil penelitian yang sudah peneliti lakukan menunjukan bahwa model pembelajaran kooperatif tipe think talk write memiliki dampak positif dalam meningkatkan hasil belajar siswa. Hal ini dapat dilihat dari semakin meningkatnya pemahaman siswa terhadap materi yang di pelajari

Dapat di simpulkan bahwa model pembelajaran kooperatif tipe ThinkTalk Write (TTW) dapat meningkatkan hasil belajar siswa kelas VIII A SMP Negeri 1 Buntulia yakni dari yang tuntas berjumlah 8 siswa (34,78\%) menjadi 20 siswa yang tuntas $(86,96 \%)$. Hal ini berarti ada peninkatan yang signifikan sebesar 52,18\%.

\section{DAFTAR PUSTAKA}

Agus, Suprijono. 2012. Cooperative Learning. Jakarta: Pustaka Belajar Ahmad, Rohani. 2004. Pengelolaan Pengajaran. Jakarta. PT. Rineka Cipta Ahmad, Susanto. 2013. Teori Belajar Dan Pembelajaran. Jakarta: Kencana Anita, Lie. 2010. Cooperative Learning. Jakarta: PT. Grasindo.

Asrori, dkk. 2009. Penelitian Tindakan Kelas(peningkatan Kompetensi Profesional Guru. Yogyakarta: Multi Pressindo

Bukhari, Umar. 2010. Ilmu Pendidikan Islam. Jakarta: Amzah.

Departemen Agama Republik Indonesia. 2004. Al-Quran dan Terjemahannya. Bandung: J-ART.

Dimyati dan Mudjiono. 2009. Belajar dan Pembelajaran. Jakarta: Rineka Cipta Mufarokah, Anissatul. 2009. Strategi Belajar Mengajar. Yogyakarta : Sukses offset Slameto. 2013. Belajar Dan Faktor - Faktor Yang Mempengaruhinya. Jakarta: Rineka Cipta

Suharsimi, Arikunto. 2010. Prosedur Penelitian: Suatu Pendekatan Praktik. Jakarta: PT Rineka Cipta

Warsono dan Hariyanto. 2013. Pembelajaran Aktif. Bandung: Remaja Rosdakarya. Zainal, Aqib. 2013. Model-model Media dan Strategi Pembelajaran Kontekstual. Bandung: Yrama Widya 